\title{
USA
}

\section{Why US electric deregulation could stall}

by Edward L. Flippen

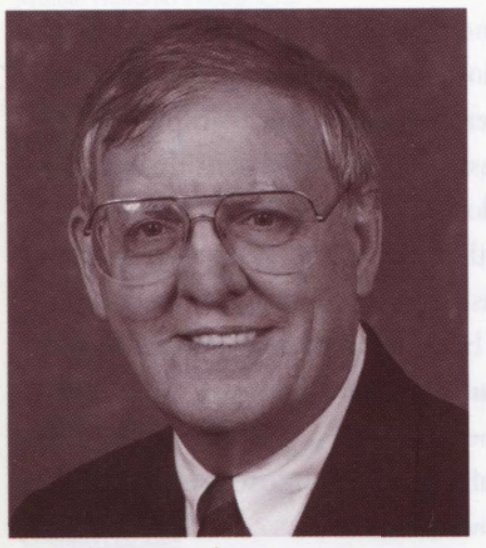

USA Today (2 August 2000) reports that power supply outages are now more likely because electric generation reserves have not kept pace with growth. A news story in Time (17 July 2000) claims that electric utility deregulation, which was supposed to Edward L. Flippen lower prices through competition, is instead causing rising prices, particularly in California and New York. Likewise, the Los Angeles Times (29 July 2000) reports that deregulation in California is increasingly being judged a costly disappointment or even failure.

\section{PRICE INCREASES}

It appears that price increases in states such as California, where deregulation is underway, are the naysayer's 'proof' that regulation - not deregulation - is best for consumers. Indeed, similar assertions are being made in states where deregulation has barely began, and particularly, by regulators who have predicted doom and gloom even before it has been fully implemented. The New York Times (8 August, 2000) has even declared in a recent editorial that '[d]eregulation has caused upheaval around the country ...'

Regrettably, given the current regulatory climate in some states where deregulation is underway, it is likely that electric deregulation 'US style' will not garner the consumer benefits that competition should produce. Simply put, competitive market prices may not develop because regulators have made it clear that they do not trust markets and so have sought to impose various layers of regulation in the name of 'consumer protection'. Even in Virginia, where the legislature studied deregulation for three years before developing electric deregulation legislation, regulators have taken steps to ensure that post-deregulation electric prices do not exceed what prices would have been 'but for' deregulation. Interestingly, this was done in the name of consumer protection.

The Virginia Electric Utility Restructuring Act will phase in electric generation competition from 2002 through 2004. It also directs regulators, beginning in
2004, to designate default suppliers to serve customers who, for various reasons, do not utilise competitive suppliers. In recent orders issued in cases involving Allegheny Power Company and Delmarva Light and Power Company, two incumbent Virginia utilities, the regulators accepted settlements negotiated by the commission staff and parties in those cases. By doing so, they made clear that generation prices for default service provided by those two utilities will be determined on a cost basis, just as if electric generation were still regulated. Such costbased pricing effectively becomes a 'price cap' in a competitive market. That means the regulators will go along with electric competition if it develops lower prices than could be determined based on the cost of existing generating facilities, but if prices rise above the cost for existing facilities, cost-based pricing will apply. In other words, electric prices will be cost or market, whichever is lower.

Sounds great, but who really believes a vibrant competitive market will develop under such circumstances? Competitors considering states imposing indefinite price ceilings will know that there is no upside potential. If prices fall, they can freely compete for customers. If prices rise, however, they will lose their customers to generating affiliates of existing utilities that are likely to be required to be the default suppliers by regulators. Why would rational businessmen and women invest in a competitive environment that has no upside? Indeed, if it is only acceptable that prices can go down, is it really a competitive market? Of course not, but it makes for good sound bites.

Fortunately, in Virginia there is still time to do things right from a long-term perspective. Though rulings in the two cases mentioned above are final, Virginia regulators are now conducting a more generic proceeding that could result in the adoption of a rational set of rules on this subject for the vast majority of Virginia's electric companies and their customers.

\section{PRICE CEILINGS}

With competition come long-term lower prices but also, short-term price fluctuations. Indeed, it is the price fluctuations that attract the long-term investment. And from such investment emerges the type of technology changes that have sustained America's unprecedented economic growth. Unfortunately, regulators, thinking they are doing the right thing for consumers by ordering price ceilings as they implement deregulation, could cripple the 
potential for significant new investment in electric generation facilities and, ultimately, the development of competitive markets and lower prices.

Their timing could not be worse. According to data developed by the North American Electric Reliability Council (NERC) and the Edison Electric Institute, significant new investment in generation will be required in the immediate future. Between 1988 and 1998, the annual consumption of electricity increased 27 per cent. During the same period, installed generating capacity increased only 9.2 per cent. The result is that capacity reserve margins have declined from 20 per cent in 1988 to 10.8 per cent in 1998 , with most of the decline occurring between 1993 and 1998 - from 16.7 per cent to 10.8 per cent or a decline of 35 per cent in just five years. That's the bad news. The good news is that after years of less than robust construction activity, the beginning of deregulation has brought a flood of proposals for new generating plants. According to a release by the Electric Power Supply Association (ESPA) (8 June 2000), new plant additions in the planning stage now total 177,000 megawatts - more than triple what was on the drawing board in October 1998. Officials with ESPA and NERC, however, caution that without the actual construction of such projects, future reserve margins will be dangerously low.

\section{SHORT-TERM INCREASES FOR LONG-TERM GAIN}

Allowing competition to develop will bring significant long-term benefits to the US economy, but prices may not always decline. For example, according to a May 1999 report by the UK Office of Electricity Regulation, average UK electric rates declined in real terms between the onset of deregulation in 1990 and 1998, although prices sometimes rose in the initial years following deregulation. But between 1995 and 1998, electric prices declined in real terms by between 18.2 per cent and 19.3 per cent, depending upon the payment terms between customers and their electric suppliers. (Customers agreeing to monthly direct debit terms received the largest reduction.) What is important is that the UK market was allowed to develop even if it meant price increases in the short term. Notably, short-term prices did increase.

The uncertainty of when and how deregulation would take place resulted in electric utilities scaling back their generation investment plans until there was more certainty about deregulation. But, just as the 'certainty picture' is developing, now some regulators are making assertions about the failure of competition before it can fully develop and other regulators are implementing pricing ceilings, thus ensuring that competition will not fully develop at all. The long and short of it is that there is more uncertainty today than there was yesterday, so there is less likelihood that businesses will make the generation investments that have been announced. Duke Energy North America, for example, has plans to build 3,000 megawatts of new generation in California, but will reconsider its plans if California re-imposes regulation, as recently proposed by Governor Davis.

There are huge resources at stake in the electric industry. Industry revenues are estimated at $\$ 200$ billion per year and total industry investment capital is around US $\$ 700$ billion - almost ten per cent of total US capital investment. The potential cost savings and technology improvements from electric deregulation could be enormous, but the benefits will only happen if state regulators are willing to accept any potential short-term pain for the long-term gain. If they consider price fluctuations as bad politics - and politics more important than economics - electric deregulation could be on the verge of stalling at a critical state in its development. If that happens, the US economy will be the loser.

\section{Edward Flippen}

McGuire Woods

Edward Flippen is a partner with McGuire Woods LLP in Richmond, Virginia, and an adjunct professor of law at the College of William and Mary, Washington and Lee University, and the University of Richmond. This paper was prepared while he was a visiting fellow at the Institute of Advanced Legal Studies at the University of London.

\section{Amicus Curiae}

\section{Submission of articles}

Readers of Amicus Curiae are welcome to submit contributions (not exceeding 3000 words) for publication. Information, including author style notes, is available on the Internet at: http://ials.sas.ac.uk/amicus.htm

\section{Please contact Julian Harris for further information at:}

Institute of Advanced Legal Studies, 17 Russell Square, London WC1B 5DR

\section{E-mail:julian.harris@sas.ac.uk}

